\title{
Growing Non-native Trees in European Forests Brings Benefits and Opportunities but Also Has Its Risks and Limits
}

\author{
Elisabeth Pötzelsberger ${ }^{1}$ (I) Heinrich Spiecker ${ }^{2} \cdot$ Charalambos Neophytou $^{1} \cdot$ Frits Mohren $^{3} \cdot$ Anna Gazda $^{4}$. \\ Hubert Hasenauer ${ }^{1}$
}

Accepted: 21 August 2020 / Published online: 12 October 2020

(C) The Author(s) 2020

\begin{abstract}
Purpose of Review Non-native tree species (NNT) raise a range of different associations and emotions - to many citizens they are just an exotic curiosity in parks, to many conservationists they are an evil to native ecosystems that should be eradicated, to a rising group of foresters they are part of the solution to climate change and an increasing timber demand, and to others they are already daily forestry business. In this review, where we also summarise the findings of the recent COST Action FP1403 (NNEXT) 'Non-native tree species for European forests: experiences, risks and opportunities', we highlight opportunities and challenges in the light of climate change, ecological risks and legislative limits of growing non-native tree species in Europe. Recent Findings Few NNT in Europe show invasive behaviour and are listed as prohibited species or as species to be monitored. A larger number of NNT is utilised in productive forestry and forest restoration due to their superior growth, valuable timber properties and good performance under harsh growing conditions. Current species distribution, experiences with success and failures and environmental concerns differ profoundly across Europe, with Western Europe overall revealing higher shares in NNT and showing a stronger interest of forestry related stakeholder groups to continue planting NNT.

Summary Many more NNT are already used in forestry than previously thought, but relatively few species have major importance in terms of area, mainly in western European countries. Diversification, mixing and avoidance of invasion in relation to NNT are necessities that are relatively new on the agenda. In contrast, provenance research of major NNT has been going on for many decades and now provides important information for climate change adaptation. Despite the limitations to the use of NNT either through legal restrictions or forest certification that differ considerably across Europe, the careful integration of a range of tested NNT also into future forest management planning shows a high potential for climate change adaptation and mitigation.
\end{abstract}

Keywords Non-native tree species $\cdot$ Invasive alien species $\cdot$ Forest plantation $\cdot$ Climate change adaptation $\cdot$ Forest reproductive material $\cdot$ Provenances

This article is part of the Topical Collection on Forest Management

Electronic supplementary material The online version of this article (https://doi.org/10.1007/s40725-020-00129-0) contains supplementary material, which is available to authorized users.

Elisabeth Pötzelsberger

elisabeth.poetzelsberger@boku.ac.at

1 Institute of Silviculture, University of Natural Resources and Life Sciences, Vienna (BOKU), Peter-Jordan-Straße 82,

1190 Vienna, Austria
2 Chair of Forest Growth and Dendroecology, Albert-Ludwigs-Universität-Freiburg, Tennenbacherstrasse 4, 79106 Freiburg, Germany

3 Department of Environmental Sciences, Wageningen University and Research, Droevendaalsesteeg 3, 6708, PB Wageningen, The Netherlands

4 Faculty of Forestry, University of Agriculture, Al. 29 Listopada 46, 31-425 Kraków, Poland 


\section{Introduction}

Non-native forest tree species (NNT) are many times a sign of human action and as such can stir mixed or opposing reactions. People may focus on the achievements made by growing NNT, but they may also perceive the 'unnaturalness' of NNT plantations and their potential environmental impact [1]. In fact, most of the European landscape and virtually all European forests have been experiencing extensive anthropogenic influence since the Neolithic time. When farmers settled in Europe (in central Europe around 5500 B.C.), they began to convert forests into arable land and allowed their cattle to graze in the forest [2]. European forests subsequently underwent different phases and types of utilisation, degradation, deforestation, re-expansion and, for the last approximately 200 years, large scale planting and therewith potentially profound alteration of the tree species composition [2].

Introduction of plants mainly for agricultural uses dates back to Phoenician and Ancient Greek time; especially the Romans distributed new horticultural crops across Europe, many of which they had obtained through trade from the Middle East or Central Asia. Similarly, tree species were introduced or translocated within Europe. This includes the common walnut (Juglans regia L.), almond (Prunus dulcis (Mill.) D.A.Webb), apricot (Prunus armeniaca L.), peach (Prunus persica (L.) Batsch), sweet chestnut (Castanea sativa Mill.), quince (Cydonia oblonga Mill.), cultivated apple (Malus domestica Borkh), Mediterranean cypress (Cupressus sempervirens L.) and more. Later, during medieval times and with the Ottoman wars, black mulberry (Morus nigra L.) and horse chestnut (Aesculus hippocastanum L.) were distributed in Europe.

A new phase of tree introductions commenced in the sixteenth century when explorers increasingly sailed the world. It is solely from this time onwards (i.e. 1492/1500) that introduced plants are commonly called neophytes. Earlier introductions are termed archeophytes. The first non-native tree species from North America was introduced in 1536 (Thuja occidentalis L.) (Wein 1930 in [3]). Many more species followed; particularly in the first half of the nineteenth century, trees from Western North America and Australia arrived [3]. While these neophytes were initially mainly grown in parks, gardens and arboreta, or by few innovative forest owners especially among noble families [4], first testing and the use in forest plantations only commenced in the nineteenth century [3]. In German speaking countries, the works of Wangenheim in the late eighteenth century $[5,6]$ were seminal, describing North-American tree species in much detail and particularly promoting species that were supposed to either grow on very poor (e.g. sandy) soils or to grow faster and produce more valuable timber than native tree species.
The opposition against non-native species is (almost) as old as the history of introduction [7]. Today, the angle points of debates on NNT are concerns about native biodiversity and the provision of ecosystem services. The species which are considered particularly harmful or invasive, however, differ among countries $[8,9]$.

This review builds upon the insights obtained from a 4-year (2014-2018) European networking project that involved 36 countries and over 200 participants, COST Action FP1403 (NNEXT) 'Non-native tree species for European forests: experiences, risks and opportunities'. In this review, we listen to the different voices, study the current literature and try to bring some arguments into perspective. We discuss potentials, risks and challenges associated with the use of non-native tree species in forestry, particularly under a changing climate, and show the range of current interests and concerns regarding non-native tree species utilisation across Europe.

\section{NNT Species in Europe}

For the purpose of this review, we define as non-native those tree species that have their post-glacial natural distribution range outside the European geographical area. In legislation, countries typically either use their national boundaries to distinguish between native and non-native or they define a non-native species as a species growing outside its natural range. The latter is similar to definitions by major international conventions or organisations [10••]. Neither of the known definitions would allow a consistent analysis of NNT across Europe, though.

Despite our simplifying definition, the number and extent of NNT in European forests are difficult to estimate. (Fig. 1) Over the centuries, most of the species have been tested and planted only at small scales. Documentation of these trials and plantations is patchy and not centrally available. National forest inventories (NFIs) are the dominant means of obtaining representative forest information, although sampling designs and information published differ profoundly among countries. Since many NNT are relatively rare and randomly distributed, NNT are not well covered by the sampling methods of NFIs. Furthermore, NFI sampling protocols usually only foresee the most common NNT. A less common NNT may therefore be recorded by its genus or even simply as 'coniferous' or 'broadleaved' tree. And despite all efforts of compiling and homogenising the diverse NFI data within Europe (e.g. through ENFIN [11] or JRC), many NFIs are not freely accessible. In COST Action NNEXT, we therefore followed the approach of collecting expert information from 34 European countries [9॰]. We revealed that at least $145 \mathrm{NNT}$ are planted in European forests (excluding trials and arboreta), almost half of which originate in North America [10••]. In contrast, the so far most extensive publicly available collation of forest tree occurrences [12] includes only 48 NNT and 7 non-native 
genera. The non-publicly available ENFIN database of 27 harmonised NFIs contains at least 63 NNT and 10 nonnative genera. Overall, the current data situation does not allow for exhaustive estimates of NNT-specific forest areas or volume shares. However, Brus and co-workers [10••] concluded that the five most common NNT are black locust (Robinia pseudoacacia L.), blue gum (Eucalyptus globulus Labill.), Sitka spruce (Picea sitchensis (Bong.) Carrière), Douglas-fir (Pseudotsuga menziesii (Mirbel) Franco) and lodgepole pine (Pinus contorta Dougl. ex Loud) (in descending order by forest area), together making up around $75 \%$ of the in total 8.5 Mha of NNT in Europe ( 4\% of the forest area). Forest Europe reports 9.5 Mha of NNT [13], but this number partly includes European species that are non-native only in some European countries. A good example is Denmark, where the $18 \%$ Norway spruce (Picea abies (L.) H.Karst.) and 5\% sycamore maple (Acer pseudoplatanus L.) in Danish forests [14] make up half of the reported NNT forest area [13].

\section{Provenances, Genetic Variability and Breeding}

\section{Provenance Research}

A high adaptive potential of the introduced tree species is the basis for tree survival and satisfying growth performance. Several important NNT originate from a large distribution range where numerous races, ecotypes and clines have evolved. For instance, Douglas-fir occurs naturally from a northern geographic latitude of $18^{\circ}$ in Mexico to $56^{\circ}$ in western Canada [15] and Northern red oak (Quercus rubra L.) origins from a vast area delimited by the Mississippi river to the west, the Atlantic to the east, the great lakes in the North and the Gulf of Mexico to the south [16]. Consequently, the adaptive and growth traits of NNT can differ significantly depending on seed origin. Provenance tests (common-garden trials) across Europe have provided valuable evidence of the intraspecific variation and adaptive capacity. Thus, well-

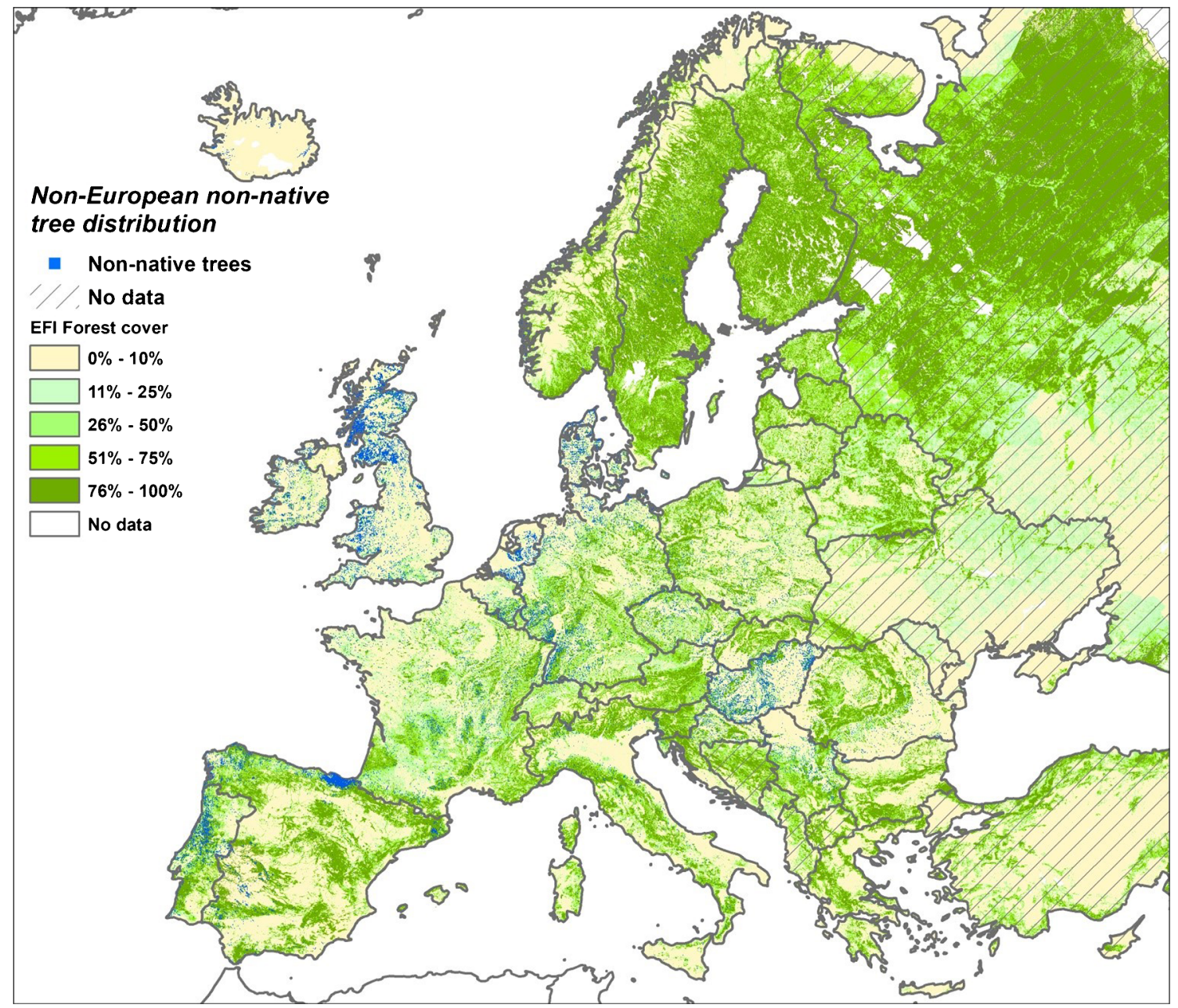

Fig. 1 NNT occurrence map based on the EU-Forest tree occurrence dataset of Mauri and co-workers [12] and additional NFIs (Belgium, Croatia, Iceland, Montenegro, Poland, Serbia and Slovenia), which we obtained directly from the country NFI responsible person or through

ENFIN. A blue dot indicates an NNT occurrence in both pure and mixed stands (mixtures may be either with native or other non-native tree species). The varying density of NNT points in parts also depends on the varying density of forest inventory points in a country 
established knowledge of frost sensitivity, height growth, stem quality characteristics and disease tolerance exists for many provenances of economically important species such as Douglas-fir, Sitka spruce, lodgepole pine and Northern red oak [17-21]. The number of provenances tested per species ranges from only a few to several hundred for NNT with a large distribution range [17]. For example, Spain only tests three provenances of Monterrey pine (Pinus radiata D.Don), as this species naturally occurs in only five small populations [22]. Particularly old NNT plantations in Europe lack documentation of seed source. In recent years, genetic fingerprinting has been increasingly used to trace back their native origin [23-27]. The accuracy of such assignments may be limited, though. Especially for species with efficient pollen and seed dispersal mechanisms (e.g. conifers, oaks), gene flow has a homogenising effect and results in little variation among gene pools in the native range.

Yet not only the native origin but also post-introduction evolution may shape growth and adaptive traits of NNT in their introduced range. Local landraces with distinct growth and adaptive characteristics may develop under natural and artificial selection. As early as the first half of the nineteenth century, empirical knowledge about local landraces has been reported on, e.g. for black locust [28]. Later, scientific evidence about the formation of local landraces was provided by provenance research. For example, growth performance of European non-native populations is often superior compared with material introduced from the native range [17, 18, 21]. Also, geographic trends of phenotypic traits in the introduced range have been revealed. For example, a latitudinal trend of bud phenology has been shown for Northern red oak (early bud burst of southern seed sources), which is opposite compared with the native range [29]. These results are indicative of a rapid evolution after introduction. Similar observations have been made in introduced populations of NNT worldwide, suggesting that such evolution may take place even within one generation from introduction [29-31]. Nonetheless, the genetic and genomic architecture of such post-introduction evolution is still rather unexplored and requires more research.

Another important question is the response of NNT to future climatic conditions. Again, provenance tests may come in handy. For instance, a provenance performing well on a warm and dry test site may be suitable for a deployment area predicted to feature such conditions in the future due to climate change. If many provenances have been tested on many replicate plots, then general trends may be derived. One way for doing this is the use of universal response functions (URFs) which predict provenance specific growth depending on the climate of the trial locations and the climatic conditions at the place of origin $[32,33]$. Multiple regression trees have served in a similar way as a tool to conclude about the performance of different provenances at given site conditions depending on the climate of origin $[34,35]$. The outcomes of these studies have been also proposed as a basis to adapt seed transfer guidelines to future climatic conditions [36, 37].

\section{Breeding Activities and Perspective}

Breeding activities for NNT in Europe differ significantly from species to species and from country to country [38, 39]. In the case of blue gum in Portugal, first breeding programmes were launched more than five decades ago. The local landrace has been the main source of plus trees and breeding populations $[40,41]$. Focus traits include susceptibility to pathogens, height and diameter growth, wood density and pulp yield. Higher heritability values have been shown for wood quality in comparison to height growth. In addition to seedlings, vegetative propagation is also applied, which enables capitalisation of genetic gains from non-additive genetic effects [40, 42, 43]. In another example, a genetic gain of about $25 \%$ for volume growth at rotation age was estimated when improved material of Sitka spruce is used in the UK [18]. For lodgepole pine in Sweden, where breeding has a tradition of more than 50 years, recent studies show the perspective of simultaneous selection for growth and stiffness [44]. For Monterrey pine in northern Spain, genetic improvement started in the 1980s and mainly focused on growth performance, branching and on frost and insect resistance. Strong adverse genetic correlation between growth and branch form prevents simultaneous breeding for both traits [22, 45].

In contrast to the aforementioned species, advancedgeneration breeding programmes are not common for Douglas-fir and Northern red oak over large parts of Central Europe, although these species are the economically most important NNT for several countries in this area. Previous activities mostly include mass selection and progeny testing for backward selection [17]. Recently, a widescale breeding program has been launched for Douglas-fir in Germany [46]. And seed orchards with simultaneous progeny testing have been proposed as a future method for genetic improvement in Northern red oak [47]. Yet, a large part of the market is supplied with seed stands, which offer a lower quality of forest reproductive material (FRM) compared with seed orchards. Given the growing demand for these two species in the face of climate change, the expansion of breeding programmes has been initiated or encouraged [47-49].

As a complimentary strategy, artificial hybridisation allows to achieve genetic gains. Being well established among fast growing poplar species [50], it has also been used in larches (e.g. hybrid larch L. x eurolepis) and walnut (e.g. hybrid between black and Persian walnut, Juglans $\mathrm{x}$ intermedia), resulting in increased growth and heterosis effects $[38,51,52]$. 


\section{Forest Reproductive Material}

The establishment of highly qualitative and adaptable forest stands for NNT depends upon the availability of FRM [53]. Currently, the national lists of approved basic material include more than 8700 seed stands, orchards and sources, parents of family and clones and clonal mixtures for NNT in the countries of the European Union and in Switzerland (Supplementary Material 1). However, FRM source types and abundance vary depending on region and species (Fig. 2). For instance, seed orchards are the main sources of qualified and tested FRM in the case of lodgepole pine in Sweden and Sitka spruce in the UK, respectively. In other cases, seed stands serve as the main seed source, e.g. for Northern red oak, where the harvesting of selected FRM (in Germany) or source identified FRM (in Hungary) may be approved (Supplementary Material 1). Certification for production of selected FRM involves phenotypic selection at the population level, but for source identified material, there are no quality requirements of the seed stand. Sources for production of qualified FRM are phenotypically selected at the individual level while tested FRM originates from basic material which has undergone progeny or clonal testing which has proved its superiority. Thus, qualified or tested FRM is generally linked to higher genetic gains than selected FRM.

Both strategies for FRM production, seed orchards and seed stands have advantages and disadvantages and are not mutually exclusive. FRM produced from seed orchards, often associated with breeding, is of higher quality. Even if it contains clones of only phenotypically selected plus-trees, a seed orchard may provide FRM leading to genetic gains of around $10 \%$, while $20-25 \%$ can be achieved in advanced breeding cycles. On the other hand, breeding is inevitably linked to losses of genetic variation and requires infusions at each new breeding cycle. As another drawback, breeding programmes require a significant investment. Seed stands

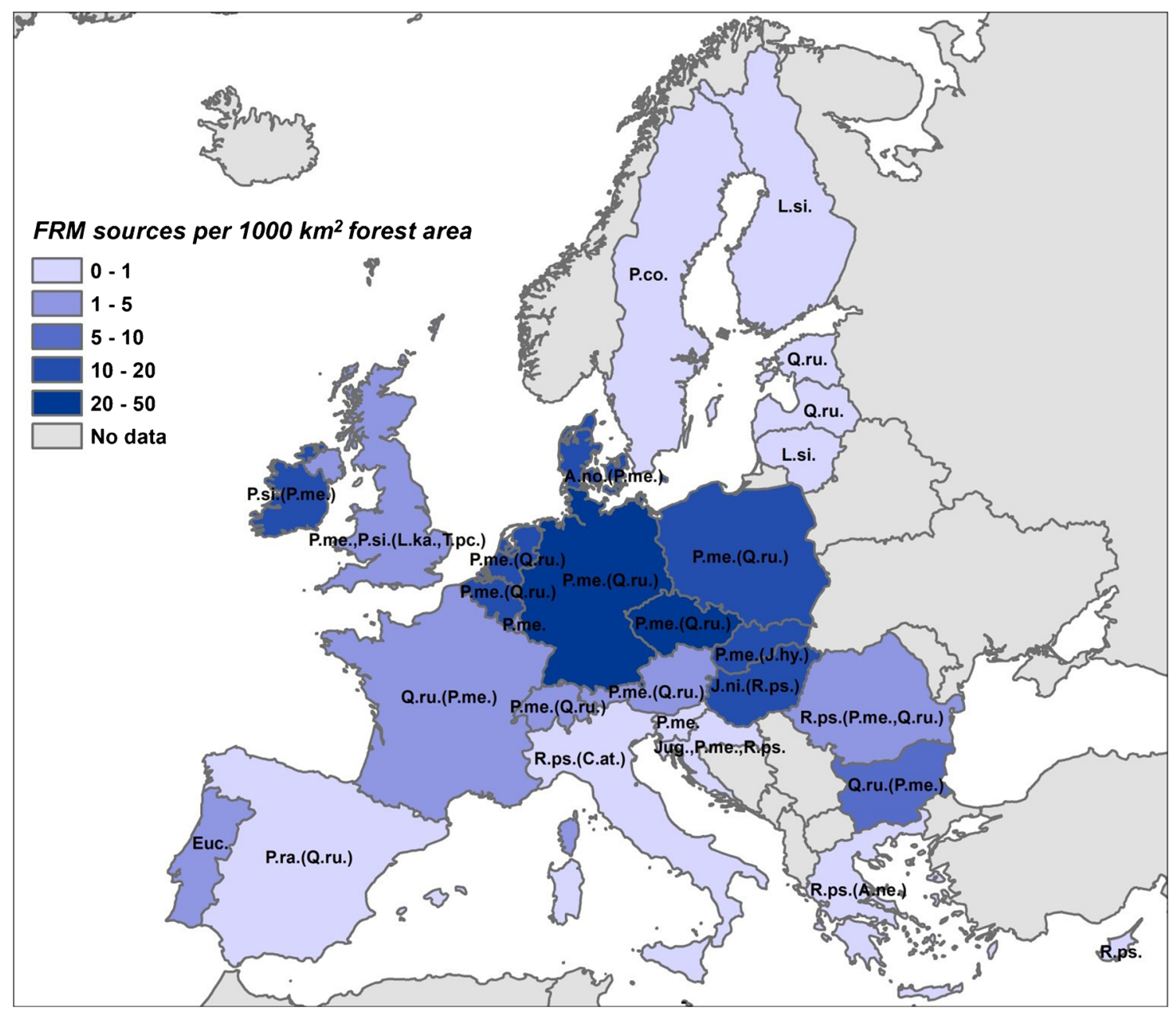

Fig. 2 Number of FRM sources per $1000 \mathrm{~km}^{2}$ forest area per country as derived from national registers of approved basic material in EU countries and Switzerland. A.ne. Acer negundo, A.no. Abies nordmanniana, C.at. Cedrus atlantica, Euc. Eucalyptus spp. and hybrids, J.hy. artificial hybrids of Juglans, J.ni. Juglans nigra, Jug. Juglans spp., L.ka. Larix kaempferi, L.si. Larix sibirica, P.me. Pseudotsuga menziesii, P.si. Picea sitchensis, P.co. Pinus contorta, Q.ru. Quercus rubra, R.ps. Robinia pseudoacacia, T.pc. Thuja plicata. Data source: see Supplementary Material 1 
offer an inexpensive alternative. However, selection at the population level, as is done for seed stands, is inefficient and cannot lead to a significant improvement of quantitative traits [54]. Especially for NNT, a further disadvantage of seed stands can be the loss of genetic diversity and even inbreeding depression. In contrast to many native species, introduced trees often lack large populations in their introduced range. Isolation of a seed stand from other populations may cause genetic drift and inbreeding depression. Legal restrictions related to stand size and number of trees within the stand may not be adequate to prevent genetic erosion due to a small effective population size, as was shown using highly variable molecular markers in the case of Douglas-fir in Central Europe [55-58]. Low germination rates, decreased seed viability and low molecular genetic diversity are among the characteristics of seed lots from European seed stands, pointing to inbreeding depression $[56,57]$.

\section{Importance Today and Opportunities for the Future}

After Europe suffered from large-scale forest degradation and lack of timber some centuries ago, huge efforts were made to restore forests. In many parts of Europe, the most commonly used species for this purpose was Norway spruce [59], a species native to cool and mountainous regions in Europe. But also other native species were planted to a considerable extent, for example silver fir (Abies alba Mill.) in the mountains of Italy, Scots pine (Pinus sylvestris L.) on sandy soils in NWEurope, maritime pine (Pinus pinaster Ait.) on swampy land in France or mountain pine (Pinus mugo Turra) on heathlands in Denmark. While native European species dominated these reforestations and afforestations, these species were often planted outside their natural range. The criteria for selecting tree species were experience, simplicity of cultivation, economic attractiveness (productivity) and in some cases the potential to improve site conditions.

Mainly during the last 100 to 200 years, plantations with highly productive NNT were established. Besides increasing productivity, NNT helped the restoration of forests at difficult sites, such as tree of heaven (Ailanthus altissima (Mill.) Swingle) on sandy soils in Austria or on karstic soils in former Yugoslavia, hybrid poplars (Populus spp.) in the flat lands of Italy, Eucalypt on swamps in Italy and black locust in continental Hungary, along mountainous railways in Switzerland or on dry slopes in Serbia and many other countries [9•].

Today, the forest area covered by NNT varies considerably among European countries (Fig. 1). While in the majority of European countries NNT still make up less than $1 \%$ of the forest area, as in Austria, Switzerland, Finland, Norway, the Baltic states and most countries on the Balkan Peninsula (except Bulgaria and Serbia), numerous countries across Europe range between 2 and 9\% NNT, and only eight countries have more than 10\% NNT forest area (Belgium, Denmark, Hungary, Iceland, Ireland, Netherlands, Portugal, United Kingdom) [9, 13]. The reasons for these differences are not always clear, and they differ among countries and regions. The specific ownership structure may play a role (overall, private forest ownership with larger freedom for species selection dominates in Western Europe as opposed to dominating state forests, and species and planting density having to be approved by the forest authority in private forests in many Eastern European countries), or the seafaring and colonial history that allowed early cross-continental trade over centuries. But also a low native tree species richness [60, 61] made testing of NNT a reasonable decision, as for instance in Ireland or Scotland where NNT shares are the highest in Europe (over 60\%).

With larger forest areas covered by NNT, their overall economic relevance rises in a country. Sitka spruce, for example, is economically highly relevant for Ireland and Great Britain, Eucalypt for the Iberian Peninsula, black locust for Hungary and Douglas-fir for France and Germany. The amount of wood locally available has an impact on NNT timber prices. In those countries such as France and Germany, where a sufficient supply of Douglas-fir wood exists, the price for this wood is higher than that of native coniferous species [62], while in countries with fewer Douglas-firs, such as Austria, the market is less developed and the wood price is lower.

Also, the perception by people and general interest in using NNT in forestry varies widely among countries (Fig. 3). In a questionnaire among NNEXT participants, we found a clear decrease from West to East in the current engagement in NNT, considering perception of different stakeholder groups, including the public and legislation. Especially in many Eastern European countries, NNT plantations are generally not appreciated today while they might have been previously, as e.g. in Bulgaria, Romania, Serbia or Slovakia where NNT still make up several percent of the forest area [9•]. The picture is not static, though. In Norway, for example, which at the time of the interview had basically completely stopped the use of NNT for reforestation and afforestation 'the Norwegian Environment Agency and the Norwegian Agriculture Agency - on request from the Ministry of Climate and Environment and the Ministry of Agriculture and Food - have recently investigated a ban on the planting of non-native tree species with high ecological risk. The Agencies' assessment is that a controlled use of non-native tree species of an extent that is recommended in the report will not result in a significant additional burden on the biological diversity in the short and long term. The Agencies believe that consideration for natural diversity, climate and industry can be safeguarded in a balanced way through management according to regulations. A ban on non-native tree species would reduce the uptake and storage of carbon in 


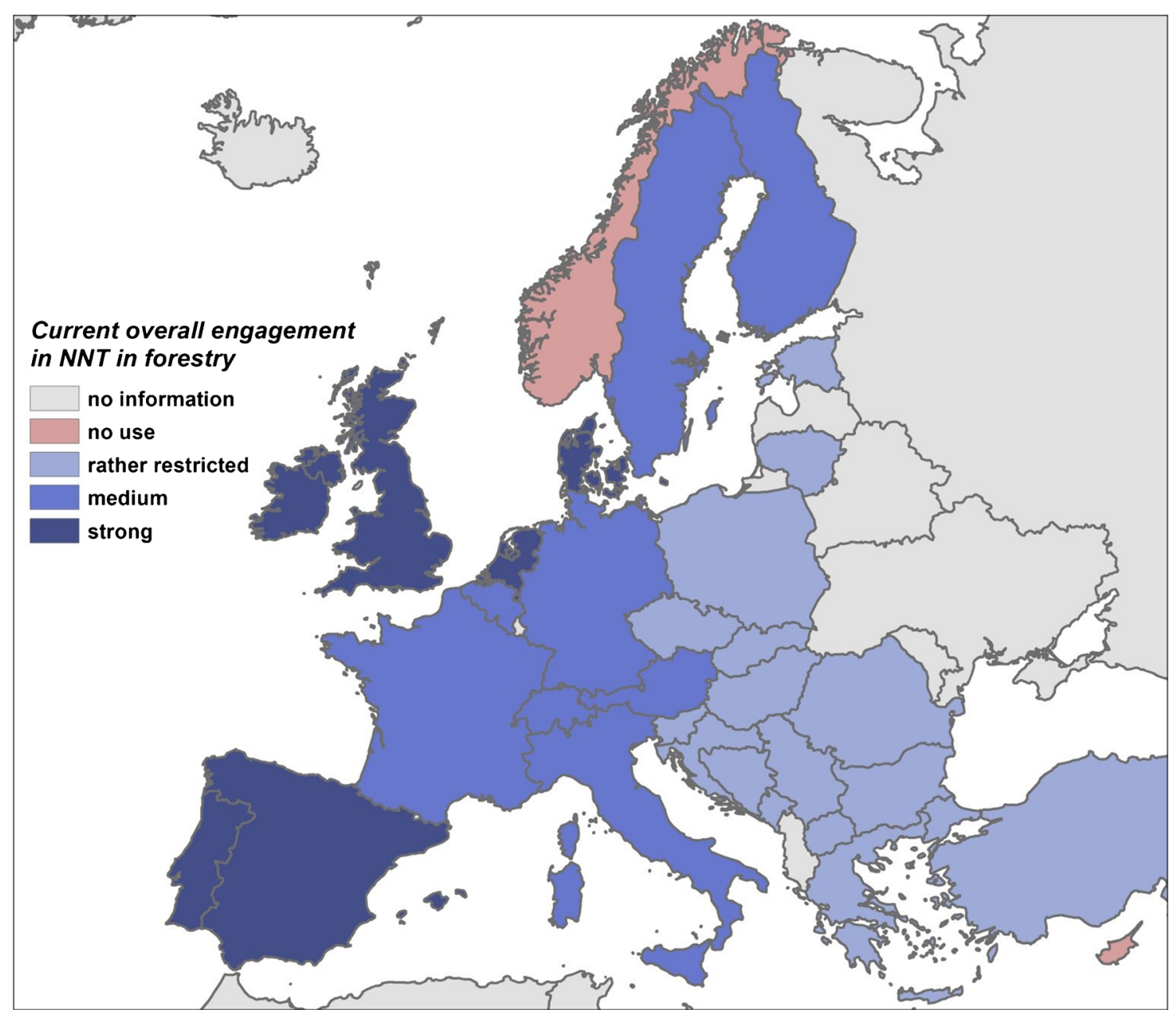

Fig. 3 Current overall engagement of European countries in NNT in forestry (i.e. interest in using NNT for reforestation and afforestation; survey among COST Action NNEXT members by H. Spiecker in 2018, unpublished)

Norwegian forests, and lead to a reduction in future access to forest raw materials.' (personal communication Per Holm Nygaard, 23.5.2019). Furthermore, the diversity among countries and stakeholder groups indicates that the engagement in NNT is not only attributable to science-based forest knowledge, but is also inspired by history, traditions, societal movements, attitudes of the land owners and of the forest authorities and political interests (e.g. implementation in legislation of biodiversity and invasiveness concerns). Interestingly, while black locust is widely accepted in South-Eastern European countries (because of its long presence in Europe and its many valuable attributes like being an important source for honey production, fire wood and having extremely durable wood), there is strong scepticism towards new(er) NNT - an attitude which is even reflected in legislation [63•]. But while NNT are often controversially discussed by the society, Vaz and coworkers [64•] found that in some regions NNT increased the cultural services and life satisfaction.

Recently, a meta-analysis on the global effects of NNT on ecosystem services has been performed [65]. That study revealed a significant enhancement of several regulating ecosystem services (climate regulation, soil erosion control, soil fertility and soil formation) and cultural ecosystem services (aesthetics, promotion on tourism websites, cultural heritage - monumental trees), but also an overall increase in the fire risk and a lower uniqueness of non-timber products was detected. While the study also showed that the total amount of timber harvested from NNT is still lower than from native species, these results are complemented with our NNEXT finding of on average $20-30 \%$ higher productivity of the most widely used NNT compared with European species [66]. Regionally, and depending on the species, the productivity gain may be much larger, e.g. in Norway and Sweden lodgepole pine growth is estimated to be 30 to $40 \%$ higher than for native Scots pine and also in Norway Sitka spruce may outperform Scots pine or birch by $200 \%$ to $300 \%$ on comparable sites [9॰].

European planted forests and timber markets are currently changing considerably. Due to concerns about biodiversity, the area of native coniferous tree species planted outside their 
natural range has been reduced in recent decades. In SouthWest Germany for example, the proportion of Norway spruce decreased from $43.5 \%$ in 1987 to $34 \%$ in 2012 . This trend is drastically enhanced by recent drought and heat weaves in combination with storms and insect infestations [67]. Consequently, adaptive species choice by foresters may favour native broadleaved tree species and in addition NNT that are supposed to be better suited for the site conditions and the expected climate [68-70]. Changes in the species composition will have consequences for the goods and services, which forests provide. This is especially true for the production of construction wood, as only about $20 \%$ of the wood of broadleaved species can be used for saw logs, while coniferous species may yield about $80 \%$ of saw logs. In order to avoid a shortage of construction wood as a crucial renewable resource and thus to avoid imports from potentially unsustainable forestry, drought tolerant coniferous NNT receive particular attention $[32,71]$.

A systematic scientific search for suitable NNT in the context of climate change can follow different approaches. Research often focuses on established species, for which the wealth of existing plantations can be used for predictions about future climatic suitability for regions which still lie in the cooler and wetter part of the occurrence spectrum, e.g. by utilising species distribution models or the statistical method random forest $[70,72]$. For a widely tested species, extensive provenance trial datasets allow the identification of provenances that are likely to show good performance under future climates [73, 74] (see also chapter 3.1). To determine key climatic variables responsible for early growth and survival, new plantations can be established along climatic gradients $[71,75]$. In our context, also one form of assisted migration is relevant [76] — assisted species migration, in the course of which species from adjacent regions southeast of Europe are transferred to Europe and tested [77•]. Recently, advances in next-generation sequencing technologies have been used in combination with a common garden setup with different provenances to formulate genomeinformed assisted gene flow strategies [78•]. Finally, also, a global search for potentially suitable species based on climatic similarities may be performed [79].

The uncertainties in the process of finding climatically suitable NNT are manifold. First, the temperature increase within a life-span of a tree cannot be accurately predicted. Second, adaptation to extreme events may be even more important than adaptation to averages of environmental variables [75]. Third, a latitudinal shift of recommended species and provenances may ignore parameters that will not change under climate change like photoperiodicity [80]. For provenances, a combined approach (mix and match) may be useful for minimising the risk of maladaptation [81]. And local landraces, which are adapted to the current site conditions, are expected to also play an important role in future FRM transfer guidelines.
Next to climate change and extreme events, European pests and pathogens are a potential threat to NNT. While NNT may be released of their natural enemies in the introduced range and for this reason may be more productive and spreading (following the enemy release hypothesis), a lack of coevolution with European pests and pathogens could make NNT particularly susceptible. It has been shown that NNT with phylogenetically closer relatives among European tree species are more attractive to native insects [82]. Besides, the number of pests and pathogens on NNT may increase with area and time since introduction $[82,83]$, which may render a formerly successful NNT unattractive. Certainly, the most prominent example is the Eastern white pine (Pinus strobus L.), which was one of the most widely planted NNT in Central Europe at the end of the nineteenth century, but was then ravaged by a native rust fungus (Cronartium ribicola J.C.Fisch.) [84].

\section{Environmental Concerns}

\section{Invasiveness}

While initial concern about the introduction of NNT was stirred by a sentiment of misplacement or even xenophobia, for example during the early days of nature conservation in Germany in the late nineteenth century $[85,86]$, the risk of biological invasion by non-native tree species in a scientific sense has been recognised as an environmental problem as early as in the 1930s, at least in South Africa [87]. Globally and with a slight delay in Europe, interest in the topic increased tremendously in the late 1990s and early 2000s [8•]. Research within invasion biology focuses on three main topics - invasiveness of species, invasibility of ecosystems and impacts of invasive species. Varying definitions of invasiveness can be encountered within science and in legislation and international conventions. They can be grouped into those definitions that focus on the ability of non-native species to spread [88] after they have overcome several barriers of introduction and establishment [89] and those definitions that in addition underline a negative environmental impact [90]. Regulation (EU) No. 1143/2014 on the prevention and management of the introduction and spread of invasive alien species belongs to the second group. The idea that invasive species can also be found among native species receives little attention in invasion biology, though [91].

Invasiveness of trees (sensu Richardson et al. 2000 [88]) has been related to numerous traits. Early research identified three important variables that govern tree spreading potential: small seed mass, short interval between large seed crops and short juvenile period [92]. In addition, features describing the tree growth were shown to affect invasiveness of pine species: seedling relative growth rate $(\mathrm{g} / \mathrm{g} /$ day; positively related to net 
assimilation rate, leaf area ratio and leaf mass ratio) and seedling specific leaf area [93]. Furthermore, a long residence time in the introduced range, the ability to tolerate low temperatures [94] and the regional frequency in the native range have been shown to increase the likelihood that a tree becomes invasive [95]. A high shade tolerance may also increase the risk of invasion in native forests [96]. In addition, in a recent global analysis, it was shown that tree species reach highest abundance in the introduced range if they are functionally similar to co-occurring species but are taller and have higher seed mass and wood density [97]. Divíšek and co-workers [98] attribute the ambiguous or contradictory results of traitinvasiveness studies to the failure of relating important traits to different stages along the introduction-naturalisation-invasion continuum. They suggest that a successful establishment primarily requires similar trait distributions (in agreement with the environmental filtering hypothesis), but for becoming invasive, established non-native species must be sufficiently different as to occupy novel niche space (more in line with the limiting similarity hypothesis). However, the limited success in drawing clear conclusions from trait comparisons of native vs. non-native species also stems from the contextdependence of the invasion success, i.e. the state of the ecosystem invaded with its particular abiotic and/or biotic constraints [99]. A good example is Douglas-fir, which only shows invasive behaviour on rocky slopes and dry, acidic or open mineral soils if light levels are high [100, 101].

In contrast to the at times rather theoretical question of the conditions for a species to become invasive (a question still of high relevance for decisions on new introductions), managers and conservationists may rather focus on the impact of NNT on natural habitats, native species and ecological processes [90]. But also this impact has a high political relevance, since costly management efforts (in the sense of combating the nonnative species) will have to focus on species with particularly adverse impact [102].

The ecological impacts that have been attributed to NNT concern a negative impact on biodiversity and a significant change of native ecosystems (e.g. increased $\mathrm{N}$-cycling by enhanced decomposition or $\mathrm{N}$-fixation leading to eutrophication, depletion of soil nutrients, change in the water budget, increase in fire risk). The processes behind this can mainly be attributed to four impact classes following the unified classification of alien species according to their environmental impact [103], i.e. competition, hybridisation, disease transmission and chemical, physical or structural impact on the ecosystem. In addition, the presence of NNT may alter food-webs and cause outbreaks of native herbivores [104]. While we cannot provide a full list of NNT that are perceived as invasive or harmful in one region or the other, we may claim that species with $\mathrm{N}$-fixing ability and particularly strong resprouting ability receive the most attention from invasion biologists and nature conservationists in Europe, i.e. black locust, several species of Acacia sp., tree of heaven, black cherry
(Prunus serotina Ehrh.) and in addition Eucalypt species on the Iberian Peninsula. But changes attributed to the occurrence of NNT also depend on the ecosystem that the NNT forest is compared with - whether it is a (near-) natural forest system, a native species plantation or any non-forest ecosystem like a grassland. Obviously, changes will be highest if compared with non-forest ecosystems (e.g. out-shading of the herbal layer), but here the tree species identity only makes a minor difference and thus effects of grassland colonisation by trees cannot be attributed to nonnatives in particular.

\section{Monitoring, Risk Assessment and Legislation}

Today, a strong research and expert community is dedicated to the topic of invasive alien species (IAS), e.g. [105-108]. Databases and information platforms from a global to a regional level collect evidence about IAS either exclusively or as part of their portfolio, e.g. [109-116]. The eradication and confinement of IAS and education about the potential risks of non-native species and the importance of preventing the introduction is pursued in countless programs and projects (e.g. LIFE Projects). Although some NNT typically appear in compilations of harmful IAS (e.g. seven woody plants are listed among ' 100 of the worst' IAS in Europe [117]), so far NNT have rarely exclusively been dealt with in international projects or initiatives. Some exceptions are the European Code of Conduct on planted forests and invasive alien species [118], and the large European projects In-Tree [119], COST Action FP1403 (NNEXT) [120] and ALPTREES [121].

The interest in IAS has not remained of scientific nature, but almost 30 years ago the issue reached the European and international political agenda in order to regulate the spread and use of alien species. In the European Union, the Council Directive 92/43/EEC on the conservation of natural habitats and of wild fauna and flora (called 'Habitats Directive') demands that Member States shall 'ensure that the deliberate introduction into the wild of any species which is not native to their territory is regulated and, if they consider it necessary, prohibit such introduction'. The United Nations Convention on Biological Diversity (CBD, 1992) calls that 'each Contracting Party shall, as far as possible and as appropriate, prevent the introduction of, control or eradicate those alien species which threaten ecosystems, habitats or species'. In June 1993 the Second Ministerial Conference on the Protection of Forests in Europe, MCPFE [122] stated that 'native species and local provenances should be preferred where appropriate.' According to the 'Mountain Forests' Protocol (1996) of the Alpine Convention (1991) countries must ensure that 'the forest reproduction material used is indigenous'. These and other international treaties and conventions influence to a varying extent legislation on non-native tree species in European countries [63•]. A recent review study of national and subnational legislations in Europe 
revealed that the intensity of regulation of NNT in forestry differs widely, ranging from only minor legislative restrictions on the use of NNT (in Ireland, the Netherlands, Denmark, Ukraine, Albania and Greece), over a list of allowed NNT, to a complete ban of NNT in forestry (in Cyprus and the German state of Berlin) [63•]. In about two thirds of the investigated legal units, a forest authority has to approve a mandatory forest management plan (and therewith the species to be planted) [63•]. A rather recent phenomenon in legislation is the obligation for a risk assessment preceding the introduction of a new non-native species (currently in force in seven European countries and four provinces). Total prohibition of single invasive species is another approach used by numerous countries. In total, $24 \mathrm{NNT}$ and two genera are prohibited through regional, national or European legislation [63•]. Following regulation (EU) No. 1143/2014 on the prevention and management of the introduction and spread of invasive alien species, the 'List of invasive alien species of Union concern' (the 'Union list') lists four alien tree species (Ailanthus altissima, Acacia saligna, Prosopis juliflora and Triadica sebifera) since its last update in 2019. Species are only listed following a thorough assessment procedure including a risk assessment and a weighing of potential costs and benefits of listing a species and of costs of in-action).

In addition to hard law, several legally non-binding soft law restrictions may influence forest management decisions, especially IAS black-lists [123] and forest certification schemes promoting sustainable forest management. In Europe, over 97 million hectares of forest are FSC certified [124], and particularly state forests are largely FSC certified [125]. The current FSC International Standard states in Criterion 10.2 that native species and local genotypes shall be used for regeneration, unless there is clear and convincing justification for using others, and according to Criterion 10.3 alien species shall only be used when knowledge and/or experience have shown that any invasive impacts can be controlled and effective mitigation measures are in place [126]. National FSC standards, which so far have been developed for about half of European countries, contain an adaptation of the International Generic Indicators [127] to the local context. Indicators to the aforementioned criteria differ considerably among countries. While in many countries maximum shares of NNT per stand or management unit are introduced (e.g. $75 \%$ on nutrient poor sites and $35 \%$ on other sites in Denmark, $20 \%$ in Germany, $5 \%$ if planted and $10 \%$ if naturally regenerating in Czech Republic), other countries, e.g. UK, allow for an unlimited use of NNT provided they improve forest growth or resilience and that invasive species can be controlled and their impact mitigated [128].

Risk assessment is considered indispensable for an early warning and information system in Europe [129] and can be defined as the evaluation of the probability of establishment, spread and related (potentially) undesirable consequences of alien species [130]. Such risk assessment schemes are manifold [131], even within Europe [132] but few are specific to tree species [100]. Consequently, results of risk assessments for the same species in the same region yield inconsistent classifications, what was recently found for several NNT assessed in Germany [133••]. The criteria for negative impacts were included in all six schemes investigated by Bindewald and co-workers [133••], whereas the spread and reproduction potential was not always considered for the assessment. Differing weights or consequences of a specific observed impact lead to different classifications and few schemes consider the extent of the area that can potentially be invaded or impacted. An ecosystem type specific risk assessment was supported by only one of the investigated assessment schemes [134] and the availability of management options to control populations feeds solely into the one assessment scheme specifically designed for NNT [100]. It can be concluded that despite the widely accepted context dependence of invasion risk of NNT, so far risk assessment schemes provide only coarse-scale classifications that rarely consider regional differences and control options as would be beneficial for a careful landscape planning that protects precious natural ecosystems and at the same time allows for the utilisation of promising NNT in selected locations.

\section{Forest Management Using NNT}

In forestry, NNT were originally introduced mainly for an increase in productivity, either because they were expected to have comparatively higher productivity or because the introduced species was expected to indirectly improve productivity through soil amelioration (as in the case of black cherry) [3]. Productive NNT were usually managed in an even-aged monoculture, resembling the common intensive production systems for native species. Typically, the original ecosystem from which a species was taken did not play a noticeable role in the way the introduced species was managed; regeneration was generally through planting, also in second rotations. This remains current practice in most regions where timber production is the primary objective, and is most obvious where NNT species are cultivated mainly for fibre production, as in the case of Eucalypt in Portugal [135]. In addition to the selection of appropriate provenances and breeding (compare chapter 3 ), intensive forest management required permanent plot research on growth and yield for the construction of yield tables and identification of appropriate thinning regimes. Site studies focussing on productivity may also include studies to establish knowledge on nutrient requirements and, possibly, fertiliser requirement.

Where NNT have gradually exhibited invasive behaviour, further silvicultural considerations have to be taken, notably when invasiveness has led to undesired establishment in 
adjacent stands, or to problems with regeneration of native species in mixed stands. A particularly promising silvicultural measure to prevent further spreading, especially of light demanding species such as black locust and tree of heaven, is to refrain from full canopy opening [136]. To avoid spreading from plantations into sensitive habitats, monitored buffer zones are an appropriate measure [100], particularly in well managed forest landscapes and for NNT that can be easily removed (species that are not resprouting and do not form root suckers).

With the increasing interest in mixed, uneven-aged stands, and increasing emphasis in biodiversity conservation and other ecosystem services besides productivity, silvicultural management also of NNT can rely less on even-aged production techniques where stand development is largely controlled by silvicultural measures [137]. Not only for enhancing biodiversity, a mixture of NNT with native tree species may be recommended [138-140], but also in cases where NNT are considered relevant for climate change adaptation [141]. In such mixed stands, invasiveness and ecological dominance of NNT can be perceived as a problem that requires adaptive management practices [136]. A related problem is the need to change from a clear-cut/planting system to natural regeneration in mixed, uneven-aged systems with small scale natural regeneration [142]. Consequently, regeneration processes as occurring in natural stands of an introduced species are becoming more relevant, requiring research on the species' regeneration strategies and the development of appropriate regeneration techniques to include NNT in overall spontaneous ecosystem dynamics. The challenge is to find a balance between the regeneration and growth dynamics of an NNT and the ecological properties of native species, while maintaining the contribution of NNT to the overall management objectives such as productivity, landscaping, and biodiversity conservation. Integration of NNT into mixed stands has turned out to be easiest when ecological properties of NNT are similar to native species, and if the NNT do not show strong dominating behaviour. A promising example is the Douglas-fir, which can be combined with native species such as Norway spruce, beech and silver fir [101]. Here, invasiveness in such mixed Douglas-fir stands is not an issue; on the contrary, Douglas-fir early growth needs to be favoured, because of its relatively high light demand.

Changing regeneration techniques and silvicultural management that includes natural (spontaneous) regeneration has implications on population genetics. Similar to what was discussed in chapter 3.3 for seed stands, isolation and the small size of a regenerating NNT stand may also lead to a genetic drift and inbreeding depression. To allow for maintenance of sufficient genetic variation, notably in view of resilience and adaptive capacity of forests under climate change, it should therefore, in small isolated stands, be aspired to extend the natural regeneration process over several years as to allow for a larger pool of parents participating in the regeneration and to perform enrichment planting to avoid a genetic bottle-neck [55].

\section{Conclusions}

The reputation of NNT and the question of the continued expansion of this group of species in Europe are loaded with hope, prejudice, scepticism or rejection. Actually, there is hardly a topic in forestry that is so controversially and emotionally discussed as non-native tree species. People may associate with NNT a wide range of opportunities to respond to global change (i.e. to the challenges arising from climate change, invasive pests and diseases, increasing demand for natural resources like biomass, construction wood, different types of timber as raw material for bio-refineries and more) or they may see tremendous risks for native ecosystems or the provision of ecosystem services. Rational decision-making is imperative to best satisfy society's desires for a range of forest ecosystem services and the need to preserve biodiversity. Long-term studies and trials, but also recent developments in forest research, provide a solid base for supporting such decisions. And in many regions in Europe, foresters can build upon experience of over 100 years of growing NNT. We are convinced that this experience and modern research findings, together with sound risk assessments (that also considers the specific site conditions and control options available as part of standard forest management operations), and with the increasing appreciation in silviculture of forest structure, mixing and landscape patterns to sustain biodiversity, modern sustainable forest management shall also in the future be permitted to rely on NNT as part of the forestry portfolio.

Acknowledgements This article is based upon information collected during COST Action FP1403 (NNEXT) 'Non-native tree species for European forests - experiences, risks and opportunities' supported by COST (European Cooperation in Science and Technology) (www.cost.eu). We express our deep gratitude to all, over 200 NNEXT participants for the open discussions and sharing of information on non-native tree species in their countries. A special thanks goes to Monika Konnert, Working Group 2 leader, and to all WG deputy leaders and sub-group leaders. We also thank the national research agencies acting as the national coordinators for COST. We extend our gratitude to Klemens Schadauer and Alexandra Freudenschuß of the Austrian Federal Research Centre for Forests, Natural Hazards and Landscape (BFW), Vienna, Thomas Riedel and Lea Henning from Johann Heinrich von Thünen Institute in Germany and Michal Bosela from the National Forest Centre in Slovakia, who were very supportive in organising occurrence information for several countries through ENFIN or directly from the national NFI responsible persons. The Joint Research Centre supported the development of the ENFIN 2016 data set within the Special Contracts No 13 and 17 of the Framework Contract 388432. Finally, we would like to acknowledge Isabella Hofmann, who did the language check.

Funding Open access funding provided by University of Natural Resources and Life Sciences, Vienna (BOKU).

\section{Compliance with Ethical Standards}

Conflict of Interest All authors state that there are no conflicts of interests to declare. 
Human and Animal Rights This article does not contain any studies with human or animal subjects performed by any of the authors.

Open Access This article is licensed under a Creative Commons Attribution 4.0 International License, which permits use, sharing, adaptation, distribution and reproduction in any medium or format, as long as you give appropriate credit to the original author(s) and the source, provide a link to the Creative Commons licence, and indicate if changes were made. The images or other third party material in this article are included in the article's Creative Commons licence, unless indicated otherwise in a credit line to the material. If material is not included in the article's Creative Commons licence and your intended use is not permitted by statutory regulation or exceeds the permitted use, you will need to obtain permission directly from the copyright holder. To view a copy of this licence, visit http://creativecommons.org/licenses/by/4.0/.

\section{References}

Papers of particular interest, published recently, have been highlighted as:

- Of importance

•- Of major importance

1. Starfinger U, Kowarik I. Praise and damnation - perceptions towards introduced tree species vary and change with time. In: Krumm F, Vítková L, editors. Introduced tree species in European forests: opportunities and challenges. Freiburg: European forest institute (EFI); 2016. p. 86-93.

2. Ellenberg H, Leuschner C. Vegetation Mitteleuropas mit den Alpen (Vegetation ecology of central Europe). 6th ed. Stuttgart: Ulmer; 2010.

3. Nyssen B, Schmidt UE, Muys B, Lei PB, van der Pyttel P. The history of introduced tree species in Europe in a nutshell. In: Krumm F, Vítková L, editors. Introduced tree species in European forests: opportunities and challenges. Freiburg: European forest institute (EFI); 2016. p. 44-54.

4. Van Loo M, Dobrowolska D. Douglas-fir distribution in Europecurrent situation. In: Spiecker H, Lindner M, Schuler J, editors. Douglas-fir - an option for Europe What Science Can Tell Us. 9th ed. Joensuu: European forest institute (EFI); 2019. p. 26-9.

5. Wangenheim FAJ. Beytrag zur teutschen holzgerechten Forstwissenschaft, die Anpflanzung Nordamericanischer Holzarten mit Anwendung auf teutsche Forste betreffend. Göttingen: J.C. Dieterich; 1787. 240 p.

6. Wangenheim FAJ. Beschreibung einiger Nordamericanischen Holz- und Buscharten, mit Anwendung auf teutsche Forsten. Göttingen: J.C. Dieterich; 1781. p. 160.

7. Booth J. Die Nordamerikanischen Holzarten und ihre Gegner [North American timber species and their opponents]. Berlin: Springer; 1896. p. 87.

8. Krumm F, Vítková L. Introduced tree species in European forests: opportunities and challenges. Freiburg: European forest institute (EFI); 2016. p. 423. Book covering many different aspects of NNT and their potential invasiveness in Europe

9. Hasenauer H, Gazda A, Konnert M, Lapin K, Mohren GMJ, Spiecker H, et al. Non-native tree species for European forests: experiences, risks and opportunities - COST Action FP1403 NNEXT country reports. In: University of Natural Resources and Life Sciences. 3rd ed. Vienna, Vienna; 2017. p. 431. Rich reports of the 36 NNEXT member countries on the occurrence, importance and risks of NNT in forestry.
10.• Brus R, Pötzelsberger E, Lapin K, Brundu G, Orazio C, Straigyte L, et al. Extent, distribution and origin of non-native forest tree species in Europe. Scand J For Res. 2019;34(7):533-44 Most actual overview on the number and area of non-native tree species in Europe.

11. ENFIN - European National Forest Inventory Network [Internet]. Available from: http://www.enfin.info/. Accessed 30 Apr 2020

12. Mauri A, Strona G, San-Miguel-Ayanz J. EU-Forest, a highresolution tree occurrence dataset for Europe. Sci Data. 2017;4:1-8.

13. FOREST EUROPE. State of Europe's forests 2015. Madrid; 2015.

14. Nord-Larsen, Thomas Johannsen VK, Riis-Nielsen, Torben Thomsen MI, Suadicani K, Vesterdal L, et al. Skove og plantager 2015: Forest statistics 2015. Frederiksberg: Institut for Geovidenskab og Naturforvaltning, Københavns Universitet; 2016.

15. Lavender DP, Hermann RK. Douglas-fir: the genus Pseudotsuga. Corvallis: Forest Research Publications Office, Oregon State University; 2014.

16. Sander IL. Quercus rubra L. Northern Red Oak. Silvics North Am, Hardwoods. 1990;2:148-52.

17. Bastien J-C, Sanchez L, Michaud D. Douglas-Fir (Pseudotsuga menziesii (Mirb.) Franco). In: Pâques LE, editor. Forest tree breeding in Europe current state-of-the-art and perspecitves. Dodrecht: Springer Science+Business Media; 2013. p. 325-69.

18. Lee S, Thompson D, Hansen JK. Sitka Spruce (Picea sitchensis (Bong.) Carr). In: Forest tree breeding in Europe. Springer; 2013. p. $177-227$.

19. Elfving B, Ericsson T, Rosvall O. The introduction of lodgepole pine for wood production in Sweden - a review. For Ecol Manag. 2001;141(1-2):15-29.

20. Daubree J, Kremer A. Genetic and phenological differentiation between introduced and natural populations of Quercus rubra L. Ann Des Sci For. 1993;50(Supplement):271s-80s.

21. Liesebach M, Schneck V. Entwicklung von amerikanischen und europäischen Herkünften der Roteiche in Deutschland. Development of American and European provenances of northern red oak in Germany. Forstarchiv. 2011;9(4):125-33.

22. Espinel S, Aragonés A. Genetic parameter estimates for Pinus radiata in Basque country, northern Spain. NZ J For Sci. 1997;27(3):272-9.

23. Merceron NR, Leroy T, Chancerel E, Romero-Severson J, Borkowski DS, Ducousso A, et al. Back to America: tracking the origin of European introduced populations of Quercus rubra L. Hipp AL, editor. Genome. 2017;60(9):778-90.

24. Costa J, Vaillancourt RE, Steane DA, Jones RC, Marques C. Microsatellite analysis of population structure in Eucalyptus globulus. Genome. 2017;60(9):770-7.

25. Hintsteiner WJ, van Loo M, Neophytou C, Schueler S, Hasenauer $\mathrm{H}$. The geographic origin of old Douglas-fir stands growing in Central Europe. Eur J For Res. 2018;137(4):447-61 One of the most comprehensive studies assigning NNT to their native origins based on molecular markers.

26. Neophytou C, Pötzelsberger E, Curto M, Meimberg H, Hasenauer H. Population bottlenecks have shaped the genetic variation of Ailanthus altissima (Mill.) Swingle in an area of early introduction. For An Int J For Res. 2020;93:495-504 Wide-scale population genetic study suggesting that natural regeneration may imply a reduction of genetic diversity in the special case of NNT.

27. Bouteiller XP, Verdu CF, Aikio E, Bloese P, Dainou K, Delcamp A, et al. A few north Appalachian populations are the source of European black locust. Ecol Evol. 2019;9(5):2398-414.

28. Poiteau MA. Notice nécrologique et historique sur M. Van Mons. In: Annales de la société royale d'horticulture de Paris. Paris: Société royale d'horticulture de Paris; 1842. p. 282-94. 
29. Merceron N Processus écologiques et évolutifs impliqués dans le succès de l'introduction de Quercus rubra L. en Europe. Université de Bordeaux; 2016.

30. Feret P, Bryant R. Genetic differences between American and Chinese Ailanthus seedlings. Silvae Genet. 1974;23(5):144-8.

31. Burdon RD, Firth A, Low CB, Miller MA. Multi-site provenance trials of Pinus radiata in New Zealand. For Genet Resour. 1998;26:3-8.

32. Chakraborty D, Wang T, Andre K, Konnert M, Lexer MJ, Matulla $\mathrm{C}$, et al. Selecting populations for non-analogous climate conditions using universal response functions: the case of Douglas-fir in central Europe. PLoS One. 2015;10(8):1-21.

33.• Chakraborty D, Schueler S, Lexer MJ, Wang T. Genetic trials improve the transfer of Douglas-fir distribution models across continents. Ecography (Cop). 2019;42(1):88-101 Analysis of growth to predict species performance and to assist seed transfer under climate change. Comprehensive study including numerous provenances and test sites for Douglas-fir.

34. Hamann A, Gylander T, Yu CP. Developing seed zones and transfer guidelines with multivariate regression trees. Tree Genet Genomes. 2011;7(2):399-408.

35. Gapare WJ, Ivković M, Liepe KJ, Hamann A, Low CB. Drivers of genotype by environment interaction in radiata pine as indicated by multivariate regression trees. For Ecol Manag. 2015;353:21-9.

36. Zhang L, Huanqiong N, Gapare WJ, Dillon SK, Li X, Wu HX. Comparison of allelic diversity between native gene resource plantings and selections in open-pollinated progeny test of Pinus radiata D. Don Silvae Genet. 2014;63(1-6):213-21.

37. Castellanos-Acuña D, Vance-Borland KW, St. Clair JB, Hamann A, López-Upton J, Gómez-Pineda E, et al. Climate-based seed zones for Mexico: guiding reforestation under observed and projected climate change. New For. 2018;49(3):297-309.

38. Konnert M, Alizoti P, van Loo M, von Wühlisch G, Karlsson B, Kroon J, et al. Short reviews on the genetics and breeding of introduced to Europe forest tree species. Studia for. Konnert M, Alizoti P, editors. Ljubljana: Slovenian Forestry Institute, Silva Slovenica publishing centre; 2018. $47 \mathrm{p}$.

39. Pâques LE. Forest tree breeding in Europe: Springer; 2013.

40. Costa e Silva J, Borralho NMG, Araújo JA, Vaillancourt RE, Potts BM. Genetic parameters for growth, wood density and pulp yield in Eucalyptus globulus. Tree Genet Genomes. 2009;5(2):291-305.

41. Borralho NMG, Almeida MH, Potts BM. O melhoramento do eucalipto em Portugal. O eucaliptal em Port impactes Ambient e Investig científica Lisboa Inst Super Agron 2007;61-110.

42. Costa e Silva J, Potts BM, Tilyard P. Stability of genetic effects across clonal and seedling populations of Eucalyptus globulus with common parentage. For Ecol Manag. 2013;291:427-35.

43. Rezende GDSP, de Resende MD V, de Assis TF. Eucalyptus breeding for clonal forestry. In: Challenges and Opportunities for the World's Forests in the 21st Century. Springer; 2014. p. 393-424.

44. Hayatgheibi H, Fries A, Kroon J, Wu HX. Estimation of genetic parameters, provenance performances, and genotype by environment interactions for growth and stiffness in lodgepole pine (Pinus contorta). Scand J For Res. 2019;34(1):1-11.

45. Codesido V, Fernández-López J. Implication of genotype $\times$ site interaction on Pinus radiata breeding in Galicia. New For. 2009;37(1):17-34

46. Liepe K, Schröder J, Wojacki J. Neue Perspektiven der Züchtung für Douglasie und Waldkiefer. AFZ-DerWald. 2015;11:27-9.

47. Steiner W. Hochwertiges Vermehrungsgut durch züchterische Verbesserung: Ein Vergleich verschiedener Möglichkeiten am Beispiel der Roteiche (Quercus rubra L.). Forstarchiv. 2012;8(2): 85-92.

48. Liesebach M, Degen B, Grotehusmann H, Janßen A, Konnert M, Rau H-M, et al. Strategie zur mittel-und langfristigen Versorgung mit hochwertigem forstlichem Vermehrungsgut durch Züchtung in Deutschland. Thünen Report; 2013.
49. Meißner M. FitForClim - Bereitstellung von leistungsfähigem und hochwertigem Forstvermehrungsgut für den klima- und standortgerechten Wald der Zukunft. In: Symposium des Verbundprojektes FitForClim vom 14 und 15 Juni 2016 in Chorin. Nordwestdeutsche Forstliche Versuchsanstalt; 2017. p. 5-12.

50. Liesebach H, Schneck V, Ewald E. Clonal fingerprinting in the genus Populus L. by nuclear microsatellite loci regarding differences between sections, species and hybrids. Tree Genet Genomes. 2010;6(2):259-69.

51. Pâques LE, Foffová E, Heinze B, Lelu-Walter M-A, Liesebach M, Philippe G. Larches (Larix sp.). In: Forest tree breeding in Europe. Springer; 2013. p. 13-122.

52. Fady B, Ducci F, Aleta N, Becquey J, Vazquez RD, Lopez FF, et al. Walnut demonstrates strong genetic variability for adaptive and wood quality traits in a network of juvenile field tests across Europe. New For. 2003;25(3):211-25.

53. Konnert M, Fady B, An Gömöry D, A'hara S, Wolter F, Ducci F, et al. Use and transfer of forest reproductive material in Europe in the context of climate change. Eur For Genet Resour Program (EUFORGEN), Bioversity Int Rome, Italy xvi. 2015;75.

54. White TL, Adams WT, Neale DB. Forest genetics. Cabi; 2007.

55. Neophytou C, van Loo M, Hasenauer H. Genetic diversity in introduced Douglas-fir and its natural regeneration in Central Europe. For An Int J For Res. 2020;93:535-44.

56. Wojacki J, Eusemann P, Ahnert D, Pakull B, Liesebach H. Genetic diversity in seeds produced in artificial Douglas-fir (Pseudotsuga menziesii) stands of different size. For Ecol Manag. 2019;438:18-24 The study highlights the effect seed stand size and isolation on parentage relationships, inbreeding and inbreeding depression in a European Douglas-fir. The study provides a scientific basis for FRM regulations and suggests that some standards may not be adequate.

57. Eckhart T, Walcher S, Hasenauer H, Van Loo M. Genetic diversity and adaptive traits of European versus American Douglas-fir seedlings. Eur J For Res. 2017;136(5-6):811-25.

58. Fussi B, Konnert M, Dounavi A. Identification of varieties and gene flow in Douglas fir exemplified in artificially established stands in Germany. Ann For Res. 2013;56(2):249.

59. Heinrich Spiecker, Hansen J, Klimo E, Skovsgaard JP, Sterba H, von Teuffel K. Norway spruce conversion-options and consequences. EFI Research Report 18. Brill: Leiden; 2004. 320 p.

60. Latham RE, Ricklefs RE. Continental comparisons of temperatezone tree species diversity. Species Divers Ecol communities 1993;294-314

61. Svenning J-C. Deterministic Plio-Pleistocene extinctions in the European cool-temperate tree flora. Ecol Lett. 2003;6(7):646-53.

62. Weber K. Starkholz aus der Sicht der Nadelholzvermarktung "Segen oder Fluch". Waldwirtschaft Priv für den Ortenaukr 2018;7-10.

63. Pötzelsberger E, Lapin K, Brundu G, Adriaens T, Andonovski V, Andrašev S, et al. Mapping the patchy legislative landscape of non-native tree species in Europe. For An Int J For Res. 2020;93:567-86 For the first time, all legislation in Europe concerning NNT used in forestry is investigated.

64. Vaz AS, Castro-Díez P, Godoy O, Alonso Á, Vilà M, Saldaña A, et al. An indicator-based approach to analyse the effects of nonnative tree species on multiple cultural ecosystem services. Ecol Indic. 2018;85:48-56.

65. Castro-Díez P, Vaz AS, Silva JS, van Loo M, Alonso Á, Aponte $\mathrm{C}$, et al. Global effects of non-native tree species on multiple ecosystem services. Biol Rev. 2019;94(4):1477-501 Global synthesis of NNT effects on the provision of ecosystem services.

66. Mohren F, Nicolescu V-N, Mason B, Spiecke H, Henin J-M, Hasenauer, H; Pötzelsberger E. Silviculture and management of non-native tree species in Europe. In: Mattos P, editor. Forest research and cooperation for sustainable development - XXV 
IUFRO World Congress, 29 sept - 5 October 2019, Curitiba, PR, Brazil Abstracts. Curitiba, Brazil: Brazilian journal of forestry research; 2019. p. 470.

67. Hlásny T, Krokene P, Liebhold A, Montagné-Huck C, Müller J, Qin H, et al. Living with bark beetles: impacts, outlook and management options. From Science to Policy 8. European Forest Institute (EFI); 2019. 50 p.

68. Đodan M, Brus R, Eisold AM, Nicolescu VN, Oršanić M, Pratasiene K, et al. Non-native tree species in the viewpoint of climate change: chances and opportunities - Croatia as a case study. Sumar List. 2018;142(7-8):391-402.

69. Bolte A, Ammer C, Löf M, Madsen P, Nabuurs GJ, Schall P, et al. Adaptive forest management in central Europe: climate change impacts, strategies and integrative concept. Scand J For Res. 2009;24(6):473-82.

70. Thurm EA, Hernandez L, Baltensweiler A, Ayan S, Rasztovits E, Bielak K, et al. Alternative tree species under climate warming in managed European forests. For Ecol Manag. 2018;430(August): 485-97.

71. Frischbier N, Nikolova PS, Brang P, Klumpp R, Aas G, Binder F. Climate change adaptation with non-native tree species in central European forests: early tree survival in a multi-site field trial. Eur J For Res. 2019;138(6):1015-32.

72. Pötzelsberger E, Eckhart T, Hasenauer H. Mapping the growth potential of Douglas-fir in Austria and Germany. Austrian J For Sci. 2019;136(2):69-86.

73. Isaac-Renton MG, Roberts DR, Hamann A, Spiecker H. Douglas-fir plantations in Europe: a retrospective test of assisted migration to address climate change. Glob Chang Biol. 2014;20(8):2607-17.

74. Chakraborty D, Wang T, Andre K, Konnert M, Lexer MJ, Matulla $\mathrm{C}$, et al. Adapting Douglas-fir forestry in Central Europe: evaluation, application, and uncertainty analysis of a genetically based model. Eur J For Res. 2016;135(5):919-36.

75. Correia HA, Almeida HM, Branco M, Tomé M, Montoya RC, Di Lucchio L, et al. Early survival and growth plasticity of 33 species planted in 38 Arboreta across the European Atlantic area. Forests. 2018;9(10):1-18.

76. Williams MI, Dumroese RK. Preparing for climate change: forestry and assisted migration. J For. 2013;111(4):287-97.

77. Stanturf JA, Madsen P, Sagheb-Talebi K, Hansen OK. Transformational restoration: novel ecosystems in Denmark. Plant Biosyst. 2018;152(3):536-46 Multifaceted reflection on the challenges of forest restoration globally and as a case study in Denmark and the value of novel ecosystems.

78.• Browne L, Wright JW, Fitz-Gibbon S, Gugger PF, Sork VL. Adaptational lag to temperature in valley oak (Quercus lobata) can be mitigated by genome-informed assisted gene flow. Proc Natl Acad Sci. 2019;116(50):25179-85 Application of a genome-wide association study based on next-generation sequencing and a common garden setup with progenies, in order to support genomeinformed strategies of assisted gene flow. Comprehensive and pioneer study in a forest tree species.

79. Schmiedinger A, Bachmann M, Kölling C, Schirmer R. Verfahren zur Auswahl von Baumarten für Anbauversuche vor dem Hintergrund des Klimawandels. How to select tree species for trials against the background of climate change? Forstarchiv. 2009;8(1):15-22.

80. Park A, Talbot C. Information underload: ecological complexity, incomplete knowledge, and data deficits create challenges for the assisted migration of forest trees. Bioscience. 2018;68(4):251-63.

81. Bucharova A, Bossdorf O, Hölzel N, Kollmann J, Prasse R, Durka $\mathrm{W}$. Mix and match: regional admixture provenancing strikes a balance among different seed-sourcing strategies for ecological restoration. Conserv Genet. 2019;20(1):7-17.

82. Branco M, Brockerhoff EG, Castagneyrol B, Orazio C, Jactel H. Host range expansion of native insects to exotic trees increases with area of introduction and the presence of congeneric native trees. J Appl Ecol. 2015;52(1):69-77.

83. Frenzel M, Brändle M, Brandl R. The colonization of alien plants by native phytophagous insects. In: 42nd IAVS Symposium, Uppsala, Sweden, July 1999. 2000. p. 223-5.

84. Radu S. Pinus strobus: past and future in Europe. A page of silvicultural history and international scientific cooperation. Ann For Res. 2008;51:133-40.

85. Weiss V. Keine Willkommenskultur für Douglasien im deutschen Walde. Arnshaugk Verlag; 2017. 164 p.

86. Eser U. Stranger in paradise. How culture shapes attitudes towards introduced species. In: Krumm F, Vítková L, editors. Introduced tree species in European forests: opportunities and challenges. Freiburg: European forest institute (EFI); 2016. p. 59-67.

87. Richardson D. The ecology of invasions by Pinus (Pinaceae) and Hakea (Proteaceae) species, with special emphasis on patterns, processes and consequences of invasion in mountain fynbos of the southwestern cape province. South Africa: University of Cape Town; 1989

88. Richardson DM, Pyšek P, Rejmánek M, Barbour MG, Dane Panetta F, West CJ. Naturalization and invasion of alien plants: concepts and definitions. Divers Distrib. 2000;6(2):93-107.

89. Blackburn TM, Pyšek P, Bacher S, Carlton JT, Duncan RP, Jarošík V, et al. A proposed unified framework for biological invasions. Trends Ecol Evol. 2011;26(7):333-9.

90. Alpert P, Bone E, Holzapfel C. Invasiveness, invasibility and the role of environmental stress in the spread of non-native plants. Perspect Plant Ecol Evol Syst. 2000;3(1):52-66.

91. Valéry L, Fritz H, Lefeuvre J-C, Simberloff D. Invasive species can also be native. Trends Ecol Evol. 2009;24(11):585.

92. Rejmánek M, Richardson DM. What attributes make some plant species more invasive. Adv Invasion Ecol. 1996;77(6):1655-61.

93. Grotkopp E, Rejmánek M, Sanderson MJ, Rost TL. Evolution of genome sie in pines (Pinus) and its life-history correlates: supertree analyses. Evolution (N Y). 2004;58(8):1705-29.

94. Pysek P, Křivánek M, Jarošik V. Planting intensity, residence time, and species traits determine invasion success of alien woody species. Ecology. 2009;90(10):2734-44.

95. Pyšek P, Jarošík V, Pergl J, Moravcová L, Chytrý M, Kühn I. Temperate trees and shrubs as global invaders: the relationship between invasiveness and native distribution depends on biological traits. Biol Invasions. 2014;16(3):577-89.

96. Ennos R, Cottrell J, Hall J, O’Brien D. Is the introduction of novel exotic forest tree species a rational response to rapid environmental change? - a British perspective. For Ecol Manag. 2019;432:718-28.

97. van der Sande MT, Bruelheide H, Dawson W, Dengler J, Essl F, Field R, et al. Similar factors underlie tree abundance in forests in native and alien ranges. Glob Ecol Biogeogr. 2020;29(2):281-94.

98. Divíšek J, Chytrý M, Beckage B, Gotelli NJ, Lososová Z, Pyšek $\mathrm{P}$, et al. Similarity of introduced plant species to native ones facilitates naturalization, but differences enhance invasion success. Nat Commun. 2018;9(1):1-10.

99. Hulme PE, Bernard-Verdier M. Comparing traits of native and alien plants: can we do better? Funct Ecol. 2018;32(1):117-25.

100. Vor T, Spellmann H, Bolte A, Ammer C, editors. Potenziale und Risiken eingeführter Baumarten. Baumartenportraits mit naturschutzfachlicher Bewertung. Vol. 7, Göttinger Forstwissenschaften. Universitätsverlag Göttingen; 2015. 233 p.

101. Spiecker H, Lindner M, Schuler JK, editors. Douglas-fir - an option for Europe. What Science Can Tell Us 9. 2019. 121 p.

102. Bartz R, Kowarik I. Assessing the environmental impacts of invasive alien plants: a review of assessment approaches. NeoBiota. 2019;43:69-99.

103. Blackburn TM, Essl F, Evans T, Hulme PE, Jeschke JM, Kühn I, et al. A unified classification of alien species based on the magnitude of their environmental impacts. PLoS Biol. 2014;12(5). 
104. Gossner MM. Introduced tree species in central Europeconsequences for arthropod communities and species interactions. In: Krumm F, Vítková L, editors. Introduced tree species in European forests: opportunities and challenges. Freiburg: European forest institute (EFI); 2016. p. 264-82.

105. ALIEN Challenge, COST Action TD1209 [Internet]. [cited $2020 \mathrm{Mar}$ 5]. Available from: https://www.brc.ac.uk/alien-challenge/home. Accessed 30 Apr 2020

106. EMAPi (Ecology and Management of Alien Plant invasions) [Internet]. Available from: http://www.ibot.cas.cz/invasions/ EMAPi_conferences/index.php. Accessed 30 Apr 2020

107. NEOBIOTA - European Group on Biological Invasions [Internet]. Available from: https://www.neobiota.eu/. Accessed 30 Apr 2020

108. IUCN SSC Invasive Species Specialist Group. Invasive Species Specialist Group [Internet]. Available from: http://www.issg.org/. Accessed 30 Apr 2020

109. European Network on Invasive Alien Species (NOBANIS) [Internet]. Available from: https://www.nobanis.org/. Accessed 30 Apr 2020

110. Invasive Species Specialist Group - ISSG. Global invasive species database [Internet]. Available from: http://www.iucngisd.org/ gisd/. Accessed 30 Apr 2020

111. European Alien Species Information Network - EASIN. Species Search and Mapping [Internet]. Available from: http://alien.jrc.ec. europa.eu/SpeciesMapper. Accessed 30 Apr 2020

112. Belgium Forum on Invasive Species - BFIS. Harmonia [Internet]. Available from: https://ias.biodiversity.be/species/all. Accessed 30 Apr 2020

113. CABI. Invasive Species Compendium [Internet]. Available from: https://www.cabi.org/isc. Accessed 30 Apr 2020

114. GBIF - Global Biodiversity Information Facility. Free and open access to biodiversity data [Internet]. [cited 2020 Apr 1]. Available from: https://www.gbif.org/. Accessed 30 Apr 2020

115. Pagad S, Genovesi P, Carnevali L, Schigel D, McGeoch MA. Data descriptor: introducing the global register of introduced and invasive species. Sci Data. 2018;5:1-12.

116. van Kleunen M, Pyšek P, Dawson W, Essl F, Kreft H, Pergl J, et al. The global naturalized alien Flora (GloNAF) database. Ecology. 2019;100(1):1-2.

117. Richardson DM, Rejmánek M. Trees and shrubs as invasive alien species - a global review. Divers Distrib. 2011;17(5):788-809.

118. Brundu G, Richardson DM. Planted forests and invasive alien trees in Europe: a code for managing existing and future plantings to mitigate the risk of negative impacts from invasions. NeoBiota. 2016;30:5-47.

119. In-Tree [Internet]. 2014 [cited 2020 Mar 5]. Available from: http:// www.in-tree.org/. Accessed 30 Apr 2020

120. COST Action FP1403 Non-native tree species for European forests: experiences, risks and opportunities (NNEX) [Internet]. 2014 [cited 2019 Aug 1]. Available from: http://nnext.boku.ac.at/. Accessed 30 Apr 2020

121. Lapin K, Bindewald A, Kraxner F, Marinšek A, La Porta N, Hazarika R, et al. A transnational cooperation for sustainable use and management of non-native trees in urban, peri-urban and forest ecosystems in the Alpine region (ALPTREES). Res Ideas Outcomes. 2020;6(33).

122. Forest Europe. Resolution H1 general guidelines for the sustainable management of forests in Europe - second ministerial conference on the protection of forests in Europe 16-17 June 1993, Helsinki/Finland. 1993.

123. Pergl J, Sádlo J, Petrusek A, Laštuvka Z, Musil J, Perglová I, et al. Black, Grey and Watch lists of alien species in the Czech Republic based on environmental impacts and management strategy. NeoBiota. 2016;28:1-37.

124. Forest Stewardship Council. FSC Facts \& Figures. 2018;12.
125. Maesano M, Ottaviano M, Lidestav G, Lasserre B, Matteucci G, Mugnozza GS, et al. Forest certification map of Europe. IForest. 2018;11(4):526-33.

126. Forest Stewardship Council. FSC International Standard. FSC principles and criteria for forest stewardship. FSC-STD-01-001 V5-2 EN. Bonn: Forest Stewardship Council; 2015.

127. Forest Stewardship Council. International Generic Indicators. Bonn; 2015. 89 p.

128. The FSC. National Forest Stewardship Standard of the United Kingdom. Bonn: Forest Stewardship Council; 2017. p. 187.

129. Genovesi P, Scalera R, Brunel S, Roy DB, Solarz W. Towards an early warning and information system for invasive alien species (IAS) threatening biodiversity in Europe. Vol. 5, EEA Report. 2010.

130. IPPC. ISPM 11 - Pest risk analysis for quarantine pests. FAO; 2017.

131. Roy HE, Rabitsch W, Scalera R, Stewart A, Gallardo B, Genovesi $\mathrm{P}$, et al. Developing a framework of minimum standards for the risk assessment of alien species. J Appl Ecol. 2018;55(2):526-38.

132. Essl F, Nehring S, Klingenstein F, Milasowszky N, Nowack C, Rabitsch W. Review of risk assessment systems of IAS in Europe and introducing the German-Austrian black list information system (GABLIS). J Nat Conserv. 2011;19(6):339-50.

133.• Bindewald A, Michiels H-G, Bauhus J. Risk is in the eye of the assessor: comparing risk assessments of four non-native tree species in Germany. For An Int J For Res. 2020;93:519-34 The authors scrutinise the methods of widely used risk assessment schemes and reveal the lack of consideration of the contextdependency of invasion.

134. D'hondt B, Vanderhoeven S, Roelandt S, Mayer F, Versteirt V, Adriaens T, et al. Harmonia + and Pandora +: risk screening tools for potentially invasive plants, animals and their pathogens. Biol Invasions. 2015;17(6):1869-83.

135. Nunes LJR, Meireles CIR, Pinto Gomes CJ, Almeida Ribeiro NMC. Historical development of the Portuguese forest: the introduction of invasive species. Forests. 2019;10:974.

136. Meloni F, Motta R, Branquart E, Sitzia T, Vacchiano G. Silvicultural strategies for introduced tree species in northern Italy. In: Krumm F, Vítková L, editors. Introduced tree species in European forests: opportunities and challenges. Freiburg: European forest institute (EFI); 2016. p. 176-89.

137. Mason WL. Implementing continuous cover forestry in planted forests: experience with Sitka spruce (Picea sitchensis) in the British Isles. Forests. 2015;6(4):879-902.

138. Oxbrough A, García-Tejero S, Spence J, O’Halloran J. Can mixed stands of native and non-native tree species enhance diversity of epigaeic arthropods in plantation forests? For Ecol Manag. 2016;367:21-9.

139. Bauhus J, Forrester DI, Pretzsch H, Felton A, Pyttel P, Benneter A. Silvicultural options for mixed-species stands. In: Pretzsch H, Forrester D, Bauhus J, editors. Mixed-species forests. Berlin: Springer; 2017.

140. Ammer C, Bolte A, Herberg A, Höltermann A, Krüß A, Krug A, et al. Empfehlungen für den Anbau eingeführter Waldbaumarten: Gemeinsames papier von Forstwissenschaft und Naturschutz. Naturschutz und Landschaftsplan. 2016;48(5):170-1.

141. Brang P, Pluess A, Bürgi A, Born J. Potenzial von Gastbaumarten bei der Anpassung an den Klimawandel. In: Pluess A, Augustin S, Brang P, editors. Wald im Klimawandel Grundlagen für Adaptationsstrategien. Bundesamt für Umwelt BAFU; 2016. p. 385-405.

142. Brang P, Spathelf $\mathrm{P}$, Larsen JB, Bauhus J, Bončína A, Chauvin C, et al. Suitability of close-to-nature silviculture for adapting temperate European forests to climate change. Forestry. 2014;87(4): 492-503.

Publisher's Note Springer Nature remains neutral with regard to jurisdictional claims in published maps and institutional affiliations. 